\title{
Glial Cell Line-Derived Neurotrophic Factor Alters Axon Schwann Cell Units and Promotes Myelination in Unmyelinated Nerve Fibers
}

\author{
Ahmet Höke, ${ }^{1}$ Tony Ho, ${ }^{1}$ Thomas 0. Crawford, ${ }^{1}$ Carl LeBel, ${ }^{2}$ Dana Hilt, ${ }^{2}$ and John W. Griffin ${ }^{1}$ \\ ${ }^{1}$ Johns Hopkins Hospital, Department of Neurology, Baltimore, Maryland 21205, and 2Amgen, Inc., Thousand Oaks, California 91320-1799
}

Glial cell line-derived neurotrophic factor (GDNF) plays an important role in the development and maintenance of a subset of dorsal root ganglion sensory neurons. We administered high-dose exogenous recombinant human GDNF (rhGDNF) daily to adult rats to examine its effect on unmyelinated axon-Schwann cell units in intact peripheral nerves. In rhGDNF-treated animals, there was a dramatic proliferation in the Schwann cells of unmyelinated fibers, which resulted in the segregation of many unmyelinated axons into a 1:1 relationship with Schwann cells and myelination of normally unmyelinated small axons. This study demonstrates that the administration of high doses of a growth factor to adult rats can change the phenotype of nerve fibers from unmyelinated to myelinated.

Key words: GDNF; myelination; Schwann cell; unmyelinated axon; sciatic nerve; Remak bundles

\section{Introduction}

During development, myelination in the peripheral nervous system occurs according to a preprogrammed sequence of events. The presumption has been that once developmental myelination is completed, a myelinated axon remains myelinated and an unmyelinated axon remains unmyelinated. There have been some documented exceptions; late in life, unmyelinated axons in the rat sympathetic nerve may myelinate over short stretches (Heath, 1982). The factors that determine the myelinated phenotype are not completely understood. Many investigators presume that specific axolemmal molecular signals are involved (Wood et al., 1990), but some data suggest that axonal caliber may be sufficient (Voyvodic, 1989); in general, unmyelinated fibers are smaller and myelinated fibers are larger. This study demonstrates that the administration of high doses of a growth factor to rats can change the phenotype of axons from unmyelinated to myelinated.

Glial cell line-derived neurotrophic factor (GDNF), a member of the transforming growth factor- $\beta$ superfamily, was initially isolated on the basis of its potent trophic effects on midbrain dopaminergic neurons in vitro (Lin et al., 1993, 1994), and subsequently was shown to be a potent trophic factor for a subset of sensory neurons as well as for sympathetic and parasympathetic neurons (Buj-Bello et al., 1995; Ebendal et al., 1995; Oppenheim et al., 1995; Trupp et al., 1995; Maxwell et al., 1996; Matheson et al., 1997; Molliver et al., 1997; Bennett et al., 1998). Early in development, all small dorsal root ganglion (DRG) neurons require nerve growth factor (NGF) for survival and express its receptors, trkA and p75. By postnatal day 15 in the rat, a subset of

Received April 22, 2002; revised 0ct. 28, 2002; accepted 0ct. 28, 2002.

This work was supported by National Institutes of Health Grants R01NS14784 and K08 NS02023-01, by the Muscular Dystrophy Association, and by the Cal Ripken Gehrig Fund for Neuromuscular Research.

Correspondence should be addressed to Dr. Ahmet Höke, Johns Hopkins Hospital, Department of Neurology, Path 509, 600 North Wolfe Street, Baltimore, MD 21205. E-mail: ahoke@jhmi.edu.

T. Ho's present address: Neuronyx Inc., Malvern, PA 19355.

D. Hilt's present address: Guilford Pharmaceuticals, Inc., Baltimore, MD 21224.

Copyright $\odot 2003$ Society for Neuroscience $\quad 0270-6474 / 03 / 230561-07 \$ 15.00 / 0$ small DRG neurons loses the expression of p75 and trkA and the ability to transport NGF retrogradely (Molliver et al., 1997). Instead, these neurons express GDNF receptors (Molliver et al., 1997), including c-ret, a tyrosine kinase receptor (Durbec et al., 1996; Trupp et al., 1996; Vega et al., 1996), and GFR- $\alpha 1$ (also known as GDNFR- $\alpha$ ), a novel glycophosphatidylinositolanchored receptor (Jing et al., 1996; Treanor et al., 1996). These cells are labeled by retrogradely transported GDNF (Molliver et al., 1997). Moreover, the deficits in the neurons that are found in GDNF-null mice and in $c$-ret-null mice suggest that GDNF plays an important role in the development of subpopulations of sensory and autonomic neurons (Schuchardt et al., 1994).

The role of GDNF in peripheral-nerve biology and pathology is clearly complex. GDNF mRNA is abundant in the epidermis (Trupp et al., 1995; Botchkareva et al., 2000), and a subset of epidermal nociceptive fibers is dependent on GDNF (Molliver et al., 1997). In peripheral nerves, Schwann cells express mRNA for GDNF and are also presumed to be a source of GDNF for peripheral neurons (Springer et al., 1994; Choi-Lundberg and Bohn, 1995; Ohi et al., 1997). In response to nerve transection, GDNF mRNA expression in Schwann cells in sciatic nerves and in DRGs rises dramatically, a finding that implicates GDNF in peripheralnerve regeneration (Trupp et al., 1995; Hammarberg et al., 1996; Hoke et al., 2000, 2002). GDNF mRNA expression is also increased in an experimental model of motor neuropathy in rats (Saita et al., 1997), in various human neuropathies (Yamamoto et al., 1997), and in traumatized human nerves (Bär et al., 1998).

To learn more about the effects of GDNF on peripheral axons and Schwann cells in vivo, we administered high doses of exogenous rhGDNF daily to adult rats and examined the changes in the nerve fibers, including myelinated fibers and the unmyelinated axon-Schwann cell unit (Remak bundles). There was a marked proliferation of Schwann cells of the Remak bundles, which was associated with increased segregation of the axons of unmyelinated fibers into smaller axon-Schwann cell units and an increase in the average diameter of unmyelinated axons. This segregation 
culminated with myelination of normally unmyelinated small axons. In parallel with the in vivo findings, we also found that GDNF supported in vitro myelination of axons by Schwann cells in DRG-Schwann cell cocultures.

\section{Materials and Methods}

Whole-animal studies. Eight-week-old adult male Sprague Dawley rats (Harlan Sprague Dawley, Indianapolis, IN) were injected intraperitoneally with either rhGDNF ( 10 or $100 \mathrm{mg} \cdot \mathrm{kg}^{-1} \cdot \mathrm{d}^{-1}$ ) or a control vehicle (saline) daily for either 1 or 4 weeks. Amgen Inc. (Thousand Oaks, CA) provided rhGDNF.

At the end of 1 and 4 weeks, rats were injected with bromodeoxyuridine (BrdU) (10 mg per 100 gm of body weight) (Sigma, St. Louis, MO) to label cells in the $\mathrm{S}$ phase. After $2 \mathrm{hr}$, the animals were perfused with $4 \%$ paraformaldehyde. A portion of the harvested sciatic nerves was also fixed in paraformaldehyde at $4^{\circ} \mathrm{C}$ for $24 \mathrm{hr}$. A second segment was removed immediately after perfusion and placed in $5 \%$ glutaraldehyde for $3 \mathrm{hr}$ for electron microscopy. This segment was postfixed in osmium tetroxide, embedded in plastic, sectioned at $1 \mu \mathrm{m}$, and stained with toluidine blue. In addition, thin sections were prepared for electron microscopy according to standard protocols (Brostoff et al., 1977).

The paraformaldehyde-fixed segments were embedded in paraffin, sectioned at $7 \mu \mathrm{m}$, and stained with hematoxylin and eosin. Other sections were immunostained with anti-BrdU (Dako, Carpinteria, CA). BrdU-labeled cells were counted in five cross sections from each sciatic nerve; the total number of labeled cells per cross section of the sciatic nerve was averaged for all of the animals in each group.

In the $1 \mu \mathrm{m}$ plastic sections stained with toluidine blue, we measured the cross-sectional area of the entire nerve and the total area occupied by myelinated fibers using a stereological method with Bioquant software (R\&M Biometrics, Nashville, TN). At the electron microscopic level, the numbers of unmyelinated axons per Schwann cell were quantified by counting the numbers of axons within one basal lamina (i.e., within one Remak bundle) in a defined area at $5000 \times$ magnification $\left(3.2 \times 10^{-4}\right.$ $\mathrm{mm}^{2}$ ). We used a nonbiased systematic sampling method. This was done by randomly choosing a grid space, and, starting from one corner, going around the outside of the grid, advancing with each move by one nonoverlapping field. In every fifth field, a photograph was taken and used to count the axons and measure the diameters of axons in the unmyelinated axon-Schwann cell units; a total of 150-600 U were counted for each animal.

Myelinating Schwann cell-DRG cocultures. Purified neuronal and Schwann cell cultures were prepared as described by Eldridge et al. (1989). The purified DRG neuronal cultures were established from Sprague Dawley rats at embryonic day 14 . The DRG neurons were dissociated with $0.25 \%$ trypsin and plated into eight well chamber slides (Nunc, Chicago, IL) that were coated with rat-tail collagen (Collaborative Research, Bedford, MA). Non-neuronal cells were eliminated by cycling with a fluorodeoxyuridine-containing medium. Neurons were then maintained for 1 week in Neurobasal medium containing $1 \%$ fetal bovine serum (HyClone, Logan, UT) and $1 \mathrm{ng} / \mathrm{ml}$ GDNF.

Schwann cells were purified by a modified Brockes method (Brockes et al., 1979). Briefly, 1-d-old rat pups were anesthetized and then killed by decapitation. Sciatic nerves were dissected, placed in L-15 medium, and treated with $0.1 \%$ collagenase followed by $0.25 \%$ trypsin to make singlecell suspensions. The cells were then plated in DMEM with $10 \%$ fetal calf serum. Cytarabine (10 mM) was added to the culture medium, followed by complement lysis with anti-thymidine 1.1 antibody to eliminate fibroblasts. The resulting culture contained $>95 \%$ Schwann cells. The Schwann cells were expanded by a medium containing pituitary extract and forskolin.

The neuronal cultures were seeded with purified Schwann cells $(10,000$ cells per well $)$ and maintained in serum-free defined medium for 1 week. During that time, the Schwann cells became associated with the axons. Myelination was induced by the addition of ascorbate $(50 \mu \mathrm{g} / \mathrm{ml})$ in $15 \%$ serum/DMEM with $1 \mathrm{ng} / \mathrm{ml}$ GDNF. To eliminate the possible contribution of endogenous NGF secreted by Schwann cells, in parallel experiments, neutralizing anti-NGF antibody $(50 \mathrm{ng} / \mathrm{ml}$; Boehringer

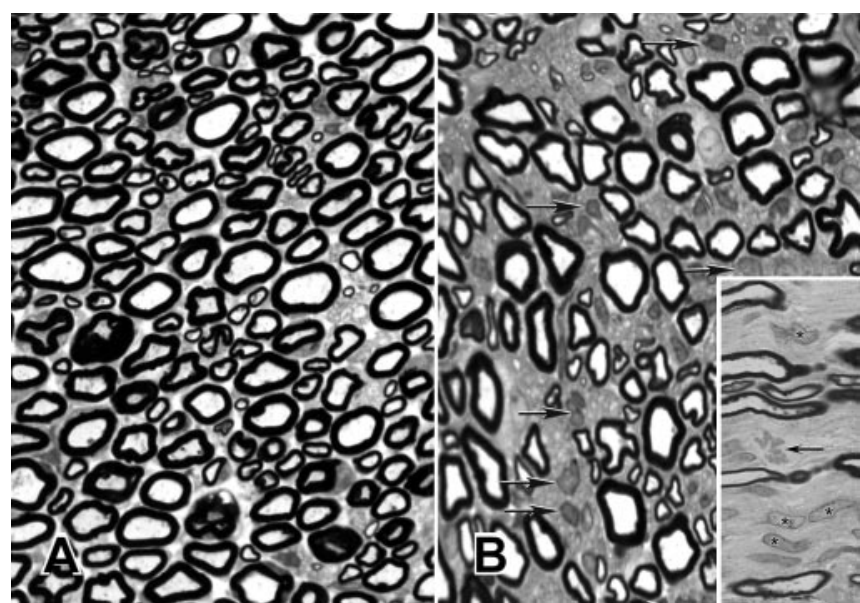

Figure 1. Toluidine blue-stained 1- $\mu \mathrm{m}$-thick sections of intact sciatic nerves of control vehicle $(A)$ and high-dose rhGDNF-injected $(B)$ rats. In rhGDNF-injected animals, the myelinated fibers were widely separated and the intervening space contained an increased number of unmyelinated Schwann cells. Examples of Schwann cell nuclei are marked by arrows in B. A mitotic figure (arrow) in a Schwann cell in an rhGDNF-injected animal is shown among other Schwann cell nuclei (asterisks) in the inset (original magnification, $1000 \times$ ).

Mannheim, Indianapolis, IN) was added to the coculture. Myelination was assessed by adding a fluorescent ceramide analog, $\mathrm{N}$-(4,4-difluoro5,7-dimethyl-4-boro-3a,4a-diaza-5-indacene-3-pentanoyl)sphingosine (BODIPY FL C5)-ceramide (Bilderback et al., 1997) (Molecular Probes, Eugene, OR). These experiments were done at least in triplicate with DRG neurons from three different sets of embryos.

\section{Results}

\section{Schwann cell proliferation}

Administration of rhGDNF resulted in an increase in the Schwann cell nuclei in the intact rat sciatic nerves (Fig. 1). By day 7 , we observed numerous mitotic figures (Fig. $1 B$, inset) in Schwann cells using electron microscopy. By day 30, in the two GDNF-treated animals, the Schwann cell nuclear densities were 2160 and 1700 nuclei $/ \mathrm{mm}^{2}$. In comparison, the Schwann cell nuclear densities from the two control animals were 582 and 825 nuclei $/ \mathrm{mm}^{2}$. This nearly threefold increase in total Schwann cell nuclei reflected proliferation, as confirmed by BrdU labeling at the end of $30 \mathrm{~d}$ of rhGDNF administration. In the intact sciatic nerves of rats receiving vehicle, only rare dividing cells ( $0.5 \mathrm{BrdU}$ labeled cells per transverse section of sciatic nerve) were found. In contrast, in all of the GDNF-treated animals there were 20 -fold increases in BrdU-labeled cells in each nerve (9.6 per transverse section of sciatic nerve). This increase in Schwann cell proliferation and myelination (see below) resulted in larger sciatic nerves in rhGDNF-treated animals. The cross-sectional areas of the sciatic nerve in GDNF-treated animals were 10.7\% larger than in the control vehicle-treated animals (mean diameter, 0.815 vs 0.736 $\mathrm{mm}^{2}$, respectively).

An increase in proliferating Schwann cells and in total Schwann cells might reflect one of the following three mechanisms: first, generation of new, noninnervated Schwann cells, either free within the endoneurial space or arranged around nerve fibers in "onion bulbs" of the type seen in some demyelinating disorders of peripheral nerve; second, Schwann cell division associated with axonal sprouting; or third, an increase in the numbers of Schwann cells ensheathing the pre-existing axons. To assess these possibilities, we examined and quantitated the axonSchwann cell relationships in the Remak bundles using electron microscopy. 


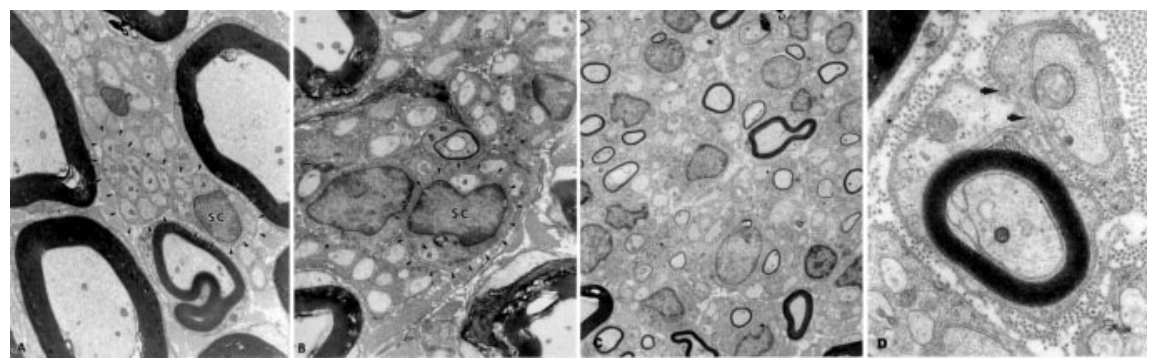

Figure 2. Segregation of axon-Schwann cell units and myelination of unmyelinated axons. A, Electron micrograph of an intact sciatic nerve of a control rat at 4 weeks. An example of an unmyelinated fiber is outlined by arrowheads on the basal lamina. This fiber contains 14 axons (examples identified by $a ; S C$, Schwann cell nucleus). B, Electron micrograph of an intact sciatic nerve of a high-dose rhGDNF-treated rat at 4 weeks. Note the marked decrease in the axon-Schwann cell ratio and numerous examples of one or two axons per Schwann cell basal lamina (examples outlined by arrowheads). C, Low-power electron micrograph of the sciatic nerve of an rhGDNF-treated rat shows examples of newly myelinated small axons. D, Some of the small myelinated fibers were still within Remak bundles that also contained unmyelinated axons, Arrowheads point to portions of the basal lamina that are continuous between a myelinated axon and an unmyelinated one (original magnifications, $5000 \times$ for $A$ and $B ; 3000 \times$ for $C$; $25,000 \times$ for $D)$.

\section{Changes in the axon-Schwann cell relationships in the Remak bundles}

\section{Normal nerve}

Rat mixed peripheral nerves normally have a characteristic pattern of large and small myelinated axons and unmyelinated axons (Fig. 1A). The myelinated axons have a 1:1 relationship with their Schwann cells, and within the basal lamina of a Schwann cell there is only one myelinated axon. In contrast, multiple unmyelinated axons are ensheathed within a single basal lamina of a Schwann cell (Remak bundles). By electron microscopy, no "free" Schwann cells (not ensheathing an axon) can be identified within the normal nerve. As shown by electron microscopy in Figure 2A, a Remak Schwann cell in the rat ensheathes several unmyelinated axons, all surrounded by one continuous basal lamina.

To quantitate the axons in each Remak bundle, we counted the number of unmyelinated axons within each complete Remak Schwann cell basal lamina. We counted all of the unmyelinated fibers in each of the nonbiased sampled "frames" of nerve. In the control group, the unmyelinated axon-Schwann cell profile ratio was 5.7 (Fig. 3) in the intact nerve.

\section{GDNF-treated nerves}

The nerves from the GDNF-treated animals showed no evidence of degeneration of either myelinated or unmyelinated nerve fibers. In addition, the epidermis of the plantar skin of the foot had a normal complement of nerve fibers (these epidermal fibers are almost exclusively sensory fibers that represent the terminals of $\mathrm{C}$ and possibly A $\delta$ fibers) (Li et al., 1997). Similarly, there was no evidence of demyelination, and there were no free Schwann cells or onion bulbs in these nerves.

The increase in Schwann cell numbers was associated with a striking reduction in the axon-Schwann cell ratio in the Remak bundles. The ratio went from 5.7 in the control group to 4.4 at 1 week and 1.9 at 4 weeks in animals treated with high-dose GDNF $\left(100 \mathrm{mg} \cdot \mathrm{kg}^{-1} \cdot \mathrm{d}^{-1}\right)$ (Fig. 3). Similar results were obtained in the low-dose GDNF group $\left(10 \mathrm{mg} \cdot \mathrm{kg}^{-1} \cdot \mathrm{d}^{-1}\right)$. Given the fact that we had similar results with each group, we combined the data from low- and high-dose animals and expressed each animal's average number of axons per Remak bundle as $n=1$. The reduction in the number of axons per Remak bundle at 4 weeks was still statistically significant (low-dose animals were 3.1 and 2.7, highdose animals were 2.2 and 1.6, controls were 6.2, 5.5, 5.6, and
5.5). Combining the groups yielded an average of 2.4 for the GDNF-treated group ( $p<0.001$ comparing the combined GDNF- vs vehicle-treated control groups).

The reduction in the axon-Schwann cell ratio can be better appreciated in the Remak bundle histograms of normal and high-dose rhGDNF-treated rats at 1 and 4 weeks (Fig. 4). In rhGDNF-treated rats, a higher percentage of axons reached a 1:1 relationship. In animals treated with a lower dose of GDNF (10 mg/kg), similar but less prominent results were obtained (data not shown).

Regeneration or sprouting of unmyelinated fibers typically passes through a phase in which Remak bundles contain very small unmyelinated axons or axons in polyaxonal pockets (Ramon y Cajal, 1928; Friede and Bischhausen, 1980). Such profiles were not seen in these nerves. The total number of unmyelinated axons per whole nerve was comparable in the control and rhGDNF-treated sciatic nerves (Table 1). Furthermore, the axon size histograms of unmyelinated axons showed an increase in the percentage of axons attaining a larger diameter, arguing against the possibility of sprouts (Fig. 5).

The most novel finding was the presence of numerous very small thinly myelinated axons in the GDNF-treated animals. These fibers, seen in the intact sciatic nerves of GDNF-treated animals, were often smaller than the smallest normal myelinated axons (Fig. 2C), and frequently contained only two to five noncompacted lamellas, reflecting ongoing myelination. Many of these fibers had attained a 1:1 relationship with their Schwann cells. These myelination profiles were usually arranged near unmyelinated fibers and sometimes shared portions of the basal lamina (Fig. 2D). Myelination of previously unmyelinated fibers was also reflected in the fact that the number of total myelinated

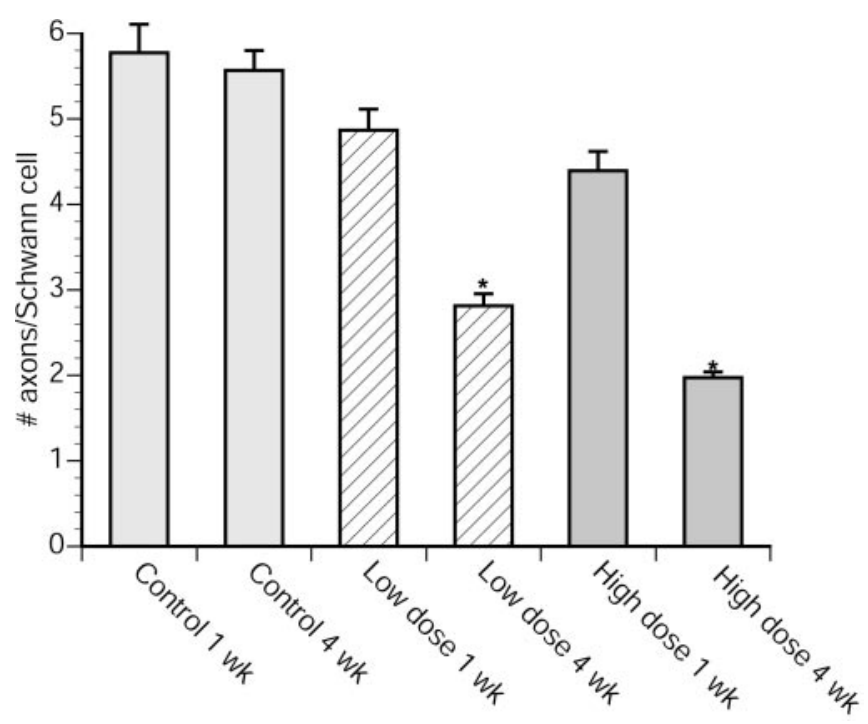

Figure 3. The ratio of unmyelinated axons per Schwann cell basal lamina in intact sciatic nerve in control animals and animals injected with either low-dose $\left(10 \mathrm{mg} \cdot \mathrm{kg}^{-1} \cdot \mathrm{d}^{-1}\right)$ or high-dose $\left(100 \mathrm{mg} \cdot \mathrm{kg}^{-1} \cdot \mathrm{d}^{-1}\right)$ rhGDNF. Each bar represents the average of $150-600$ fiber counts combined from different grids. Error bars indicate SEM. ${ }^{*} p<0.005$. 

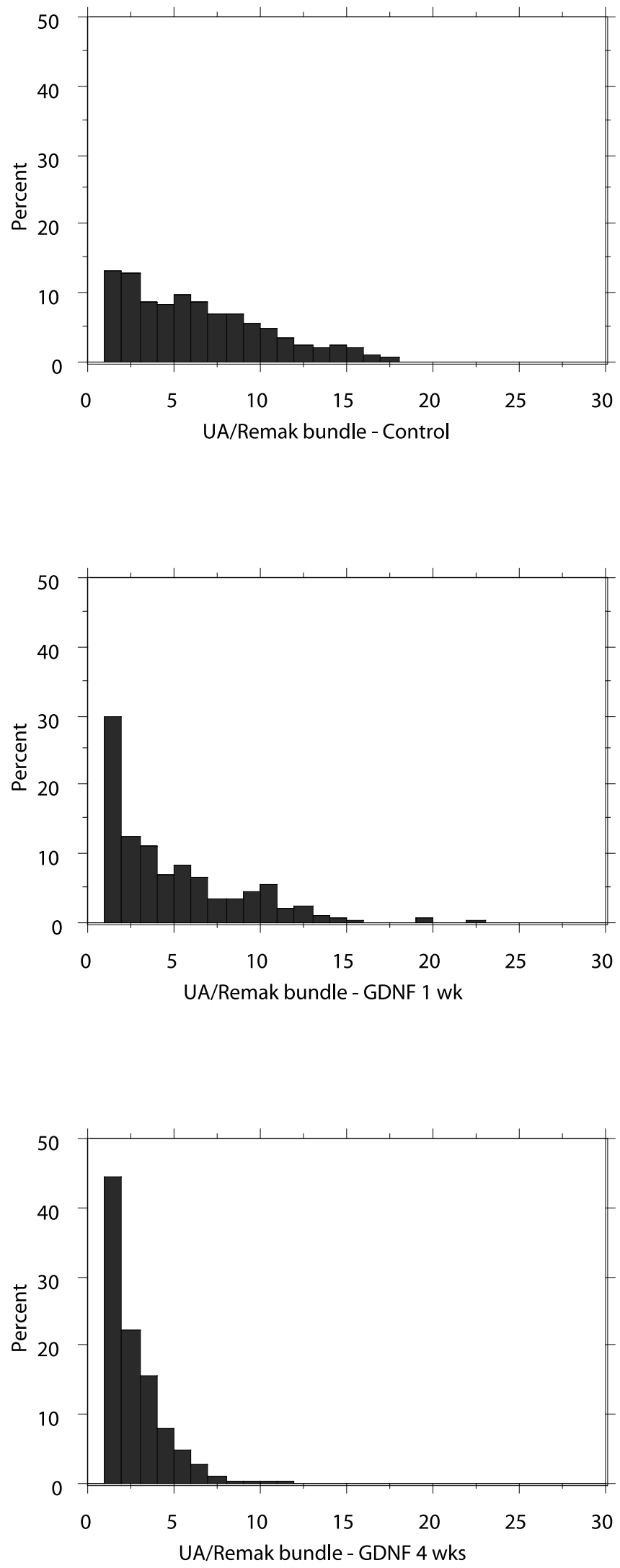

Figure 4. Histograms of the number of axons within a single Schwann cell basal lamina showed a dramatic shift to a higher percentage of Remak bundles, attaining a 1:1 relationship when the rats were treated with rhGDNF for 4 weeks $(C)$ compared with controls $(A)$. The shift was apparent even at 1 week (B). UA, Unmyelinated axon. axons per sciatic nerve was increased in rhGDNF-treated animals (Table 1).

\section{Myelinating DRG-Schwann cell cocultures}

Our in vivo experiments suggested that GDNF might induce myelination in sensory neurons. We established in vitro experiments to determine whether GDNF was permissive for myelination of DRG neurons in coculture experiments. DRG-Schwann cell cocultures were established in media containing exogenous rhGDNF but without any other exogenous neurotrophic factor, including NGF. Myelination was induced by the addition of ascorbic acid. After 1 week, clear myelination, with the formation of nodes of Ranvier, was evident (Fig. 6A). The myelinated nerve fibers expressed myelin-associated glycoprotein (MAG) in the paranodal and Schmidt-Lanterman incisures (Fig. 6B). When a fluorescent ceramide analog, BODIPY FL C5-ceramide, was included in the culture media, numerous myelinated fibers incorporated the fluorescent ceramide into the myelin (Fig. 6C). In control coculture experiments in which ascorbic acid was added but exogenous rhGDNF was omitted, there was no myelination, despite the presence of serum in the media.

As a separate control, to eliminate the possible contribution of endogenous NGF secreted by Schwann cells (in response to GDNF) or presence of NGF in the serum, neutralizing anti-NGF antibody was added to the rhGDNF-supplanted coculture. With the addition of ascorbic acid, myelination proceeded at the normal rate compared with the rhGDNF-supplanted coculture without the anti-NGF antibody (Fig. 6D). However, in the NGFsupported coculture (without exogenous rhGDNF), the addition of neutralizing anti-NGF antibody resulted in the death of DRG neurons within days, before any myelination could take place (data not shown).

\section{Discussion}

Tissue-culture studies have shown that four agents, NGF (Wood et al., 1990; Bahr et al., 1991), progesterone (Koenig et al., 1995), insulin-like growth factor-1 (Russell et al., 1998), and brainderived nerve growth factor (Chan et al., 2001) can sustain or increase the myelination of small axons in vitro. Our in vitro data have shown that GDNF is another agent capable of sustaining the myelination of nerve fibers. The most striking findings were made when high doses of exogenous rhGDNF were given to rats in vivo. There were profound changes in Remak bundles: an increase in Schwann cell numbers, a marked reduction in the number of axons per axon-Schwann cell unit, increased segregation of the axon-Schwann cell units into a 1:1 ratio, an increase in the percentage of axons attaining a larger diameter, and myelination of normally unmyelinated fibers. Schwann cell proliferation, the segregation to a 1:1 relationship between axons and Schwann cells, and the presence of early stages of myelination of very small fibers are all features of the normal sequence during developmental myelination. GDNF is the first exogenous agent known to produce such increased segregation and myelination in vivo.

\section{Myelination of small axons}

We conclude that GDNF in vivo promoted myelination of a population of axons that would otherwise remain unmyelinated. As confirmed in the control animals in the present study, by 8 weeks of age only rare fibers were undergoing active myelination. In GDNF-treated animals, there was abundant myelination of very small fibers, and some fibers were clearly undergoing early stages of myelination, with only a few wraps of noncompacted myelin. That these fibers were originally axons of unmyelinated fibers was 
Table 1. Numbers of myelinated and unmyelinated axons in control and rhGDNF-treated rats

\begin{tabular}{llllr}
\hline & Animal 1 & \multicolumn{1}{c}{ Animal 2 } & Animal 3 & \multicolumn{1}{c}{ Animal 4 } \\
\hline Vehicle-treated & $10,804(18,465)$ & $9,089(13,075)$ & $11,191(18,259)$ & $9,888(18,282)$ \\
rhGDNF-treated & $15,718(18,276)$ & $10,473(16,738)$ & $15,717(17,511)$ & $13,246(15,738)$ \\
\hline
\end{tabular}

The numbers of myelinated and unmyelinated (in parentheses) axons per nerve in vehicle control or rhGDNF-injected animals at 4 weeks are shown. There was an increase in the number of myelinated axons in rhGDNF-treated rats ( $p=$ 0.038). The differences in the number of unmyelinated axons were not statistically significant ( $p=0.978$ ). Myelinated axons were counted at $1000 \times$ magnification using unbiased stereological methods and Bioquant software. Unmyelinated axons were counted at $5000 \times$ magnification using unbiased sampling methods.

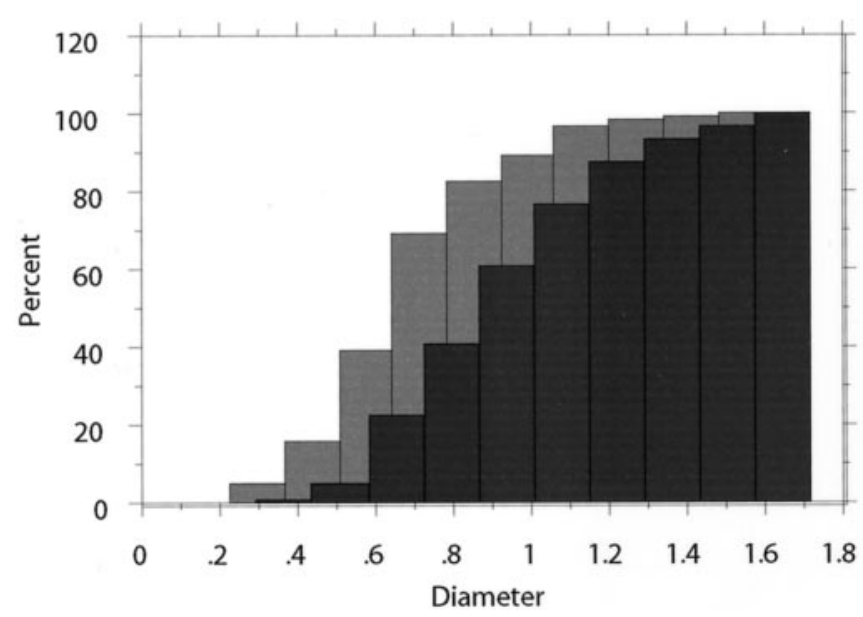

Figure 5. Cumulative line histograms of the diameter of unmyelinated axons in Remak bundles of vehicle-injected control animals and high-dose rhGDNF-injected animals show a shift to larger size.

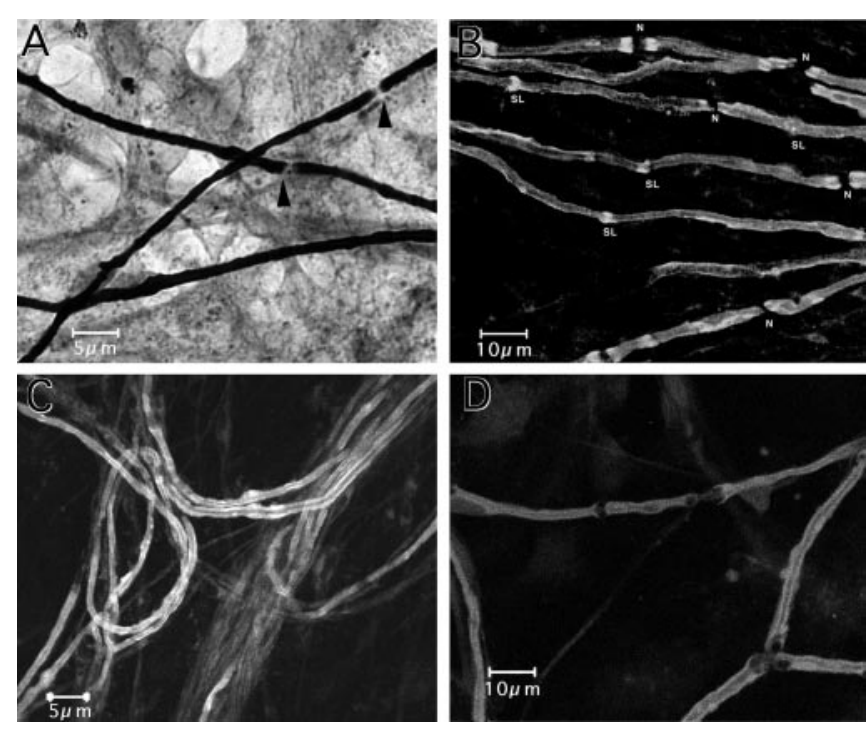

Figure 6. Schwann cell and DRG cocultures in the presence of GDNF. A, Sudan black staining shows clear myelination, with the formation of nodes of Ranvier (arrowheads). B, The myelinated nerve fibers express MAG in the paranodal ( $N$ ) and Schmidt-Lanterman $(S L)$ incisure. $C$, With the addition of a fluorescent ceramide analog to the culture medium, numerous myelinated fibers could be observed by incorporation of the fluorescent ceramide into the myelin. $D$, When neutralizing anti-NGF antibody was added to the coculture, myelination appeared to proceed at the normal rate compared with the control culture as assessed by the incorporation of fluorescent ceramide analog.

suggested by their presence within a single continuous basal lamina that also encircled unmyelinated fibers; no such profiles occur normally. Notably, these myelinating profiles occur in intact nerves with neither nerve-fiber degeneration nor, more importantly, axonal sprouting. Regenerative sprouting proceeds to myelination through a sequence similar to that of developmental myelination. There was no morphologic evidence of sprouting of unmyelinated axons. Regenerating sprouts are expected to have unusually small calibers (Brown et al., 1976), and at the early stages may be clustered in polyaxonal pockets. We saw neither of these features in the rhGDNF-treated animals. The unmyelinated axons in rhGDNF-treated animals were larger, not smaller, than their counterparts in vehicle-treated animals. These results are comparable with those in previous studies on the fiber composition of the rat sciatic nerve (Schmalbruch, 1986).

The conclusion that GDNF may promote the myelination of axons that are normally unmyelinated is also supported by our in vitro studies. GDNF substituted for NGF in the ability to maintain a population of small sensory neurons. Similar to NGF, when Schwann cells were cocultured and then "triggered" by the addition of ascorbate, they promptly began myelination. A virtually identical sequence has been found with NGF (Moya et al., 1980). The present study demonstrates the ability of GDNF to support small sensory neurons in culture and promote myelination. We ruled out the possibility that endogenous NGF was secreted by cells in our system by showing that myelination proceeded normally even with the addition of neutralizing anti-NGF antibody.

The only in vivo findings comparable with the present ones are those of Voyvodic (1989), who studied the effect of partial denervation of the mouse salivary gland. In that model, many of the remaining previously unmyelinated nerve fibers underwent myelination. These data were interpreted to suggest that each of the neurons of the sympathetic ganglia that still innervated the salivary gland had sprouted and innervated more gland cells, and as a result received an above normal amount of retrogradely transported NGF from the target cells. Our data suggest that upregulation of GDNF in an injured nerve or partially denervated target could potentially be an alternative explanation to Voyvodic's observations. It is possible that exogenous rhGDNF acted on the unmyelinated axons in a manner similar to that proposed for NGF by Voyvodic's (1989). In a more recent study, when GDNF was overexpressed in the skin of transgenic mice, the numbers of both myelinated and unmyelinated axons were increased in the saphenous nerve (Zwick et al., 2002). The data obtained by Zwick et al. (2002) suggest that target-derived excess GDNF may have rescued a population of unmyelinated sensory neurons that would normally undergo programmed cell death and induced myelination in a subpopulation of these axons.

\section{Segregation to a 1:1 relationship}

In normal development, the process of Schwann cell proliferation in fibers that are to be myelinated continues until there is a 1:1 relationship between an axon and a Schwann cell in the segment to be myelinated. This segregation is an obligatory antecedent to myelination (Morris et al., 1972; Webster, 1993); there are a few descriptions of myelination of more than one axon by the same Schwann cell, but these examples are rare (Waxman, 1968; Jaros and Bradley, 1979; Beuche and Friede, 1984). The process of segregation occurred in the GDNF-treated nerves in very much the same way as seen during development. Division of the Schwann cells associated with unmyelinated axons, reflected in 
mitotic figures and BrdU labeling, resulted in two daughter Schwann cells sharing a portion of the now loose and serpentine original basal lamina that continued to surround the daughter fibers. The threefold reduction in the mean axon-Schwann cell ratio after treatment with GDNF reflects the sizable number of fibers achieving a 1:1 relationship. It is noteworthy that this reduced ratio provides additional evidence against the presence of regenerative axonal sprouting in these nerves, because sprouting increases the axon-Schwann cell ratio.

\section{Schwann cell proliferation}

GDNF administration was associated with nearly a 20 -fold increase in proliferation, primarily affecting the Schwann cells of Remak bundles in sciatic nerves. Although BrdU uptake data do not distinguish the possibility that other cells, such as endoneurial fibroblasts or resident macrophages, may also participate, the electron microscopic observations that most of the mitotic figures are in the Schwann cells suggest that the Schwann cells of unmyelinated fibers are the predominant contributors. There are two possible sites of action of GDNF in eliciting this proliferative response in Schwann cells and in myelination of unmyelinated axons. Although GDNF may be acting directly on the Schwann cell, we favor the possibility that GDNF may be indirectly stimulating this Schwann cell response through changes in the unmyelinated axons, perhaps simply by increasing the calibers (Voyvodic, 1989) of GDNF-dependent $c$-ret-expressing unmyelinated axons, or possibly by inducing the release of glial growth factor (Brockes et al., 1980). This effect may underlie the proliferative response of Schwann cells during myelination. Nevertheless, the possibility that GDNF might be acting directly on the Schwann cells remains. Schwann cells express GFR- $\alpha 1$, one of the coreceptors for GDNF (Nosrat et al., 1997; Trupp et al., 1997; Bär et al., 1998). GFR- $\alpha 1$ does not posses an intracellular domain; and traditionally GDNF action is thought to require the formation of the GFR- $\alpha 1$ and the Ret tyrosine kinase coreceptor complex (Airaksinen et al., 1999). However, signaling through GFR- $\alpha 1$ by GDNF can occur even in the absence of Ret coreceptor (Poteryaev et al., 1999; Trupp et al., 1999; Pezeshki et al., 2001).

\section{Is the effect of GDNF on axons or Schwann cells?}

Because a population of small DRG neurons giving rise to unmyelinated axons bears the $c$-ret GDNF receptor, an attractive reconstruction is that GDNF produced axonal enlargement, which in turn drove the Schwann cell proliferation to the 1:1 relationship and myelination. Arguably, an increase in the unmyelinated axon caliber alone might be responsible for this effect. The unmyelinated axons in the rhGDNF-treated animals were larger than in the controls. Myelinated axons are in general larger than unmyelinated axons (Duncan, 1934; Webster, 1971), and some authors have postulated that axonal caliber is the signal for myelination (Friede, 1972; Voyvodic, 1989). However, the role of caliber is complex. In tissue culture, Windebank et al. (1985) found that as axons increase in size as they segregate into a $1: 1$ relationship, and there is an additional increase in caliber as they myelinate. Nonmyelinated segments of axons are smaller, have fewer neurofilaments, and have lower levels of phosphorylation of neurofilament-heavy chain (NF-H) than myelinated segments of the same axons (Hsieh et al., 1994). Demyelination results in loss of caliber and NF-H phosphorylation (de Waegh et al., 1992). Finally, signaling may occur through the GFR $\alpha-1$ in the absence of $c$-ret receptor (Poteryaev et al., 1999; Trupp et al., 1999;
Pezeshki et al., 2001). For these reasons, it is premature to ascribe the GDNF effect to either axons or Schwann cells.

In summary, we have demonstrated that GDNF administered exogenously has profound effects on unmyelinated fibers. It induces the proliferation of Schwann cells and causes segregation of unmyelinated axons into a 1:1 relationship with their Schwann cells, whereby these unmyelinated fibers are induced to myelinate. The physiological correlates of these changes are unknown. These findings suggest that GDNF may be a useful tool to study the molecular events in the myelination of peripheral nerves.

\section{References}

Airaksinen MS, Titievsky A, Saarma M (1999) GDNF family neurotrophic factor signaling: four masters, one servant? Mol Cell Neurosci 13:313-325.

Bahr M, Hopkins JM, Bunge RP (1991) In vitro myelination of regenerating adult rat retinal ganglion cell axons by Schwann cells. Glia 4:529-533.

Bär KJ, Saldanha GJF, Kennedy AJ, Facer P, Birch R, Carlstedt T, Anand P (1998) GDNF and its receptor component Ret in injured human nerves and dorsal root ganglia. NeuroReport 9:43-47.

Bennett DLH, Michael GJ, Ramachandran N, Munson JB, Averill S, Yan Q, McMahon SB, Priestley JV (1998) A distinct subgroup of small DRG cells express GDNF receptor components and GDNF is protective for these neurons after nerve injury. J Neurosci 18:3059-3072.

Beuche W, Friede RL (1984) Naked axon bundles enclosed by single segments of myelin sheaths in the nerves of non-dystrophic C57BL-ob/ +mice. Neuropathol Appl Neurobiol 10:369-377.

Bilderback TR, Chan JR, Harvey JJ, Glaser M (1997) Measurement of the rate of myelination using a fluorescent analogue of ceramide. J Neurosci Res 49:497-507.

Botchkareva NV, Botchkarev VA, Welker P, Airaksinen M, Roth W, Suvanto P, Muller-Rover S, Hadshiew IM, Peters C, Paus R (2000) New roles for glial cell line-derived neurotrophic factor and neurturin: involvement in hair cycle control. Am J Pathol 156:1041-1053.

Brockes JP, Fields KL, Raff MC (1979) Studies on cultured rat Schwann cells. I. Establishment of purified populations from cultures of peripheral nerve. Brain Res 165:105-118.

Brockes JP, Lemke GE, Balzer Jr DR (1980) Purification and preliminary characterization of a glial growth factor from the bovine pituitary. J Biol Chem 255:8374-8377.

Brostoff SW, Levit S, Powers JM (1977) Induction of experimental allergic neuritis with a peptide from myelin P2 basic protein. Nature 268:752-753.

Brown MJ, Martin JR, Asbury AK (1976) Painful diabetic neuropathy: a morphometric study. Arch Neurol 33:164-171.

Buj-Bello A, Buchman VL, Horton A, Rosenthal A, Davies AM (1995) GDNF is an age-specific survival factor for sensory and autonomic neurons. Neuron 15:821-828.

Chan JR, Cosgaya JM, Wu YJ, Shooter EM (2001) Neurotrophins are key mediators of the myelination program in the peripheral nervous system. Proc Natl Acad Sci USA 98:14661-14668.

Choi-Lundberg DL, Bohn MC (1995) Ontogeny and distribution of glial cell line-derived neurotrophic factor (GDNF) mRNA in rat. Brain Res Dev Brain Res 85:80-88.

de Waegh SM, Lee VM, Brady ST (1992) Local modulation of neurofilament phosphorylation, axonal caliber, and slow axonal transport by myelinating Schwann cells. Cell 68:451-463.

Duncan D (1934) A relation between axon diameter and myelination determined by measurement of myelinated spinal root fibers. J Comp Neurol 60:437.

Durbec P, Marcos-Gutierrez CV, Kilkenny C, Grigoriou M, Wartiowaara K, Suvanto P, Smith D, Ponder B, Costantini F, Saarma M, Sariola H, Pachnis V (1996) GDNF signalling through the Ret receptor tyrosine kinase. Nature 381:789-793.

Ebendal T, Tomac A, Hoffer BJ, Olson L (1995) Glial cell line-derived neurotrophic factor stimulates fiber formation and survival in cultured neurons from peripheral autonomic ganglia. J Neurosci Res 40:276-284.

Eldridge CF, Bunge MB, Bunge RP (1989) Differentiation of axon-related Schwann cells in vitro. II. Control of myelin formation by basal lamina. J Neurosci 9:625-638. 
Friede RL (1972) Control of myelin formation by axon caliber (with a model of the control mechanism). J Comp Neurol 144:233-252.

Friede RL, Bischhausen R (1980) The fine structure of stumps of transected nerve fibers in subserial sections. J Neurol Sci 44:181-203.

Hammarberg H, Piehl F, Cullheim S, Fjell J, Hokfelt T, Fried K (1996) GDNF mRNA in Schwann cells and DRG satellite cells after chronic sciatic nerve injury. NeuroReport 7:857-860.

Heath JW (1982) Double myelination of axons in the sympathetic nervous system. J Neurocytol 11:249-262.

Hoke A, Cheng C, Zochodne DW (2000) Expression of glial cell linederived neurotrophic factor family of growth factors in peripheral nerve injury in rats. NeuroReport 11:1651-1654.

Hoke A, Gordon T, Zochodne DW, Sulaiman OA (2002) A decline in glial cell-line-derived neurotrophic factor expression is associated with impaired regeneration after long-term Schwann cell denervation. Exp Neurol 173:77-85.

Hsieh ST, Kidd GJ, Crawford TO, Xu Z, Lin WM, Trapp BD, Cleveland DW, Griffin JW (1994) Regional modulation of neurofilament organization by myelination in normal axons. J Neurosci 14:6392-6401.

Jaros E, Bradley WG (1979) Atypical axon-Schwann cell relationships in the common peroneal nerve of the dystrophic mouse: an ultrastructural study. Neuropathol Appl Neurobiol 5:133-147.

Jing S, Wen D, Yu Y, Holst PL, Luo Y, Fang M, Tamir R, Antonio L, Hu Z, Cupples R, Louis JC, Hu S, Altrock BW, Fox GM (1996) GDNF-induced activation of the ret protein tyrosine kinase is mediated by GDNFR- $\alpha$, a novel receptor for GDNF. Cell 85:1113-1124.

Koenig HL, Schumacher M, Ferzaz B, Thi AN, Ressouches A, Guennoun R, Jung-Testas I, Robel P, Akwa Y, Baulieu EE (1995) Progesterone synthesis and myelin formation by Schwann cells. Science 268:1500-1503.

Li Y, Hsieh ST, Chien HF, Zhang X, McArthur JC, Griffin JW (1997) Sensory and motor denervation influence epidermal thickness in rat foot glabrous skin. Exp Neurol 147:452-462.

Lin LF, Doherty DH, Lile JD, Bektesh S, Collins F (1993) GDNF: a glial cell line-derived neurotrophic factor for midbrain dopaminergic neurons. Science 260:1130-1132.

Lin LF, Zhang TJ, Collins F, Armes LG (1994) Purification and initial characterization of rat B49 glial cell line-derived neurotrophic factor. J Neurochem 63:758-768.

Matheson CR, Carnahan J, Urich JL, Bocangel D, Zhang TJ, Yan Q (1997) Glial cell line-derived neurotrophic factor (GDNF) is a neurotrophic factor for sensory neurons: comparison with the effects of the neurotrophins. J Neurobiol 32:22-32.

Maxwell GD, Reid K, Elefanty A, Bartlett PF, Murphy M (1996) Glial cell line-derived neurotrophic factor promotes the development of adrenergic neurons in mouse neural crest cultures. Proc Natl Acad Sci USA 93:13274-13279.

Molliver DC, Wright DE, Leitner ML, Parsadanian AS, Doster K, Wen D, Yan Q, Snider WD (1997) IB4-binding DRG neurons switch from NGF to GDNF dependence in early postnatal life. Neuron 19:849-861.

Morris JH, Hudson AR, Weddell G (1972) A study of degeneration and regeneration in the divided rat sciatic nerve based on electron microscopy. II. The development of the "regenerating unit." Z Zellforsch Mikrosk Anat 124:103-130.

Moya F, Bunge MB, Bunge RP (1980) Schwann cells proliferate but fail to differentiate in defined medium. Proc Natl Acad Sci USA 77:6902-6906.

Nosrat CA, Tomac A, Hoffer BJ, Olson L (1997) Cellular and developmental patterns of expression of Ret and glial cell line-derived neurotrophic factor receptor $\alpha$ mRNAs. Exp Brain Res 115:410-422.

Ohi T, Takechi S, Ohta M, Furukawa S, Nakayama T, Matsukura S (1997) Neurotrophic factors produced by rat immortalized Schwann cell line. Paper presented at Peripheral Nerve Society Meeting, Cambridge, UK, July.

Oppenheim RW, Houenou LJ, Johnson JE, Lin LF, Li L, Lo AC, Newsome AL, Prevette DM, Wang S (1995) Developing motor neurons rescued from programmed and axotomy-induced cell death by GDNF. Nature 373:344-346

Pezeshki G, Franke B, Engele J (2001) Evidence for a ligand-specific signaling through GFR $\alpha-1$, but not GFR $\alpha-2$, in the absence of Ret. J Neurosci Res 66:390-395.
Poteryaev D, Titievsky A, Sun YF, Thomas-Crusells J, Lindahl M, Billaud M, Arumae U, Saarma M (1999) GDNF triggers a novel ret-independent Src kinase family-coupled signaling via a GPI-linked GDNF receptor $\alpha 1$. FEBS Lett 463:63-66.

Ramon y Cajal S (1928) Degeneration and regeneration of the nervous system. New York: Hafner.

Russell JW, Cheng H-L, Feldman EL (1998) Insulin-like growth factor-I (IGF-I) promotes neuronal myelination in peripheral sensory neurons (PSN). Neurology 50:A28-A29.

Saita K, Ohi T, Hanaoka Y, Takechi S, Nakayama T, Matsukura S (1997) Expression of GDNF and BDNF mRNA in experimental acrylamide neuropathy in rats. Paper presented at the Peripheral Nerve Society Meeting, Cambridge, UK, July.

Schmalbruch H (1986) Fiber composition of the rat sciatic nerve. Anat Rec 215:71-81.

Schuchardt A, D'Agati V, Larsson-Blomberg L, Costantini F, Pachnis V (1994) Defects in the kidney and enteric nervous system of mice lacking the tyrosine kinase receptor Ret. Nature 367:380-383.

Springer JE, Mu X, Bergmann LW, Trojanowski JQ (1994) Expression of GDNF mRNA in rat and human nervous tissue. Exp Neurol 127:167-170.

Treanor JJ, Goodman L, de Sauvage F, Stone DM, Poulsen KT, Beck CD, Gray C, Armanini MP, Pollock RA, Hefti F, Phillips HS, Goddard A, Moore MW, Buj-Bello A, Davies AM, Asai N, Takahashi M, Vandlen R, Henderson CE, Rosenthal A (1996) Characterization of a multicomponent receptor for GDNF. Nature 382:80-83.

Trupp M, Ryden M, Jornvall H, Funakoshi H, Timmusk T, Arenas E, Ibanez CF (1995) Peripheral expression and biological activities of GDNF, a new neurotrophic factor for avian and mammalian peripheral neurons. J Cell Biol 130:137-148.

Trupp M, Arenas E, Fainzilber M, Nilsson AS, Sieber BA, Grigoriou M, Kilkenny C, Salazar-Grueso E, Pachnis V, Arumae U, Sariola H, Saarma M, Ibanez CF (1996) Functional receptor for GDNF encoded by the c-ret proto-oncogene. Nature 381:785-788.

Trupp M, Belluardo N, Funakoshi H, Ibanez CF (1997) Complementary and overlapping expression of glial cell line-derived neurotrophic factor (GDNF), c-ret proto-oncogene, and GDNF receptor- $\alpha$ indicates multiple mechanisms of trophic actions in the adult rat CNS. J Neurosci 17:3554-3567.

Trupp M, Scott R, Whittemore SR, Ibanez CF (1999) Ret-dependent and -independent mechanisms of glial cell line-derived neurotrophic factor signaling in neuronal cells. J Biol Chem 274:20885-20894.

Vega QC, Worby CA, Lechner MS, Dixon JE, Dressler GR (1996) Glial cell line-derived neurotrophic factor activates the receptor tyrosine kinase RET and promotes kidney morphogenesis. Proc Natl Acad Sci USA 93:10657-10661.

Voyvodic JT (1989) Target size regulates calibre and myelination of sympathetic axons. Nature 342:430-433.

Waxman SG (1968) Peripheral nerve axon processes sharing common myelin sheaths. Brain Res 7:469-473.

Webster HD (1971) The geometry of peripheral myelin sheaths during their formation and growth in rat sciatic nerves. J Cell Biol 48:348-367.

Webster HD (1993) Development of peripheral nerve fibers. In: Peripheral neuropathy (Dyck PJ, Thomas PK, Griffin JW, Low PA, Poduslo JF, eds), pp 243-266. Philadelphia: Saunders.

Windebank AJ, Wood P, Bunge RP, Dyck PJ (1985) Myelination determines the caliber of dorsal root ganglion neurons in culture. J Neurosci 5:1563-1569.

Wood P, Moya F, Eldridge C, Owens G, Ranscht B, Schachner M, Bunge M, Bunge R (1990) Studies of the initiation of myelination by Schwann cells. Ann NY Acad Sci 605:1-14.

Yamamoto M, Mitsuma N, Ito Y, Mitsuma T, Li M, Doyu M, Sobue G (1997) Expression of GDNF, ret, and GDNFR mRNA in normal and diseased human peripheral nervous system. Paper presented at the Peripheral Nerve Society Meeting, Cambridge, UK, July.

Zwick M, Davis BM, Woodbury CJ, Burkett JN, Koerber HR, Simpson JF, Albers KM (2002) Glial cell line-derived neurotrophic factor is a survival factor for isolectin B4-positive, but not vanilloid receptor 1-positive, neurons in the mouse. J Neurosci 22:4057-4065. 